\title{
A Confessional Letter
}

\author{
Bill Pearson
}

Sir,

There are currently two differing accounts of the authorship of a six-line squib on the young James $\mathrm{K}$. Baxter. The squib in question is

Mrs Baxter's little Jim

Got immersed in sex and sin.

When the pangs of doubt grow violent

Beer's the universal solvent.

But in between the rum and vomit

A poem flashes like a comet.

According to $\mathrm{W}$. H. Oliver in James K. Baxter, a Portrait (1983) and, following him, New Zealand Wit and Wisdom, compiled by Jim Weir (1998), I am the author. According to Frank McKay in The Life of James K. Baxter (1990) 'it was said to have come from Glover' (106). Gordon Ogilvie in Denis Glover: His Life (1999), repeats this attribution.

Since errors in biography go on repeating themselves, I feel the need to relieve Denis Glover's memory of the doubtful honour and claim the verse as my own.

The circumstances of writing it were these: in 1948 I was editor of the Canterbury University College students' paper Canta and Jim Baxter was literary editor. Halfway through the year, however, pressure of studies caused me to retire and the editorship passed to Christine Clark. For the last issue of the year Christine organised a page of mutual self-congratulation with cartoons of Baxter, herself and me accompanied by some teasing verse. Ray Copeland, then a fellow M.A. student of English chose to adapt some of Chaucer's lines (on his Clerk) to go beneath the sketch of me, and I wrote the lines about Baxter. I recall the bad rhyme of the second couplet worried me at the time.

I should add that Frank McKay misread the squib when he saw it as 'pie in [Baxter's] face' or thought that the first line was suggested by Baxter's first visit, in the company of his mother, to the Caxton Press. The spirit in which it was written was that of a good-natured taunt from one young man to a close friend, and the first line was suggested by the pride I heard in Millicent Baxter's voice speaking of her son when two other students and I paid a call of homage to

Kōtare 2, no. 2 (1999), pp. 46-47. 
Archibald Baxter at Brighton in 1941. It wasn't coined by Glover especially for Baxter. It was common among young men of my generation to speak of one another in jest as 'Mrs Surname's little First-name.'

I doubt if Baxter ever saw the lines. When the issue of Canta appeared, he and Jacquie had left Christchurch for the North Island to marry.

Though Frank McKay did interview me at length for his biography, the question of the squib did not come up and there was no reason why it should. Frank, though he was terminally ill at the time, promised to correct the error, along with others I pointed out to him, the most important of which was the misnaming of the Otago medical student Baxter had been so painfully in love with (Jane Aylward, whose parents I had known in Blackball in 1942, not 'Aylmer'). When a second edition appeared, I checked that Jane's name had been corrected, and didn't worry that the squib had been overlooked.

But mistakes like this can develop a life of their own, and trivial and tedious though it is, it is my responsibility to put it right.

Yours

Bill Pearson

Kōtare 2, no. 2 (1999), pp. 46-47. 